\title{
Position taking and field level change: Capability Brown and the changing British landscape
}

Andrew Wild, University of Nottingham, UK

Andy Lockett, University of Warwick, UK

Graeme Currie, University of Warwick, UK

\begin{abstract}
How does a social actor in a disadvantaged position achieve field-level change? Using a longitudinal case of "Capability" Brown, an individual rising from humble origins to shape and refine the British landscape, we examine how an actor's unfolding efforts to move from a social position at the periphery of a field, to a social position at the centre of a field, may present them with opportunities to influence field level change. In doing so we employ Bourdieu's (1977) Theory of Practice, and unexplored notion of "position taking" (Bourdieu, 1993). We argue that an actor's tactics to shape change, and position-taking to enhance social position, should be considered in conjunction with one-another, and that position-taking strategies may be viewed as a core component of the work undertaken by social actors in trying to influence field-level change. Further, we suggest that tensions between an agent's accumulated capital and the social position typically afforded to their role in the field, may lead to efforts to "take" or "create" new positions, providing opportunities to influence the developing institution, with symbolic capital playing a pivotal role.
\end{abstract}

\section{Keywords}

Social Position, Agency, Social Actor, Field-level Change, Institutional Change

\section{Introduction}


Field theorists suggest that rather than being static, fields are constantly being changed and reproduced (Fligstein, 2013). Fields are not distinct arenas of social activity, they overlap and influence other fields. One field can be a source of exogeneous influence upon another (Fligstein \& McAdam, 2011). As socially constructed arenas, fields are shaped by actors who vie for advantage with differing resource endowments (Bourdieu \& Wacquant, 1992; Fligstein, 2013; Martin, 2003). Opportunities for change are always present, and whether change is enacted depends on whether actors are able to implement the tactics, and marshall the necessary resources, to take advantage of them. Hence, insight is required into social actors' tactics in shaping fields: "how do they spread their ideas, build political coalitions, persuade others and create new identities?" (Fligstein, 2001: 122-3). Accordingly, our focus is to examine the dynamics of social action in an organizational field, with particular attention on how an actor's work to promote field level change, both shapes and is shaped by, their location in the field.

To frame our work we draw on field theorists' concept of social position (see Sauder, 2008) and the "theory of practice" proposed by Bourdieu (1977), to conceptualise the interaction between actors and the context in which they are located (Battilana, 2006, 2011; Lockett et al., 2014). For Bourdieu, fields are "structured spaces of (social) positions whose properties depend on their position within these spaces and which can be analysed independently of the characteristics of their occupants (which are partly determined by them)" (Bourdieu 1993a: 72). Each actor is located in a unique social position, as defined by his or her control of the capital resources (e.g. economic, cultural, and social) accumulated through their lived experience (Bourdieu, 1986). Hence, social actors vie with each other to influence a field, but with differing resource endowments (Bourdieu \& Wacquant, 1992). Commonly actors at the centre of a field will have the greatest capital endowments and will dominate the field, however, as they are most likely to benefit from the existing field level 
arrangements, they will commonly lack agency to promote significant change away from the current form. In contrast, actors located in peripheral social positions are less likely to benefit from existing field level arrangements, and are more likely to be exposed to contradictions in current institutions, through being exposed to (or being part of) alternative fields (Haveman \& Rao, 1997; Seo \& Creed, 2002). Accordingly, peripheral actors are motivated to enact significant field level change, however, they commonly lack the capital endowments to be able to do so (Lockett et al., 2014).

As fields are not static, being changed and reproduced constantly (Fligstein, 2013), it is important to account for actors being situated in time as well as space (Battilana, 2006). To understand how an actor's social position influences their motivation and ability to enact field level change, it is necessary to account for changes in an actor's social position over time. Study of this transition, as a key factor in field level change, remains absent from current scholarship (Battilana, 2006; Lockett et al., 2014), but is the focus of our study. We do so because, although literature has re-balanced the structure-agency debate away from structural determinism, it projects an overly heroic and hyper-muscular portrayal of individuals as powerful change agents (Suddaby \& Viale, 2011). In its "search for drama", it has failed to adequately consider the institutional context of agency (Smets, Morris, \& Greenwood, 2012: 880). Rather than being "unleashed actors" (Powell \& Colyvas, 2008: 277), framed by the wider structural context in which they are located, actors may slowly re-shape their social position over time, and in so doing re-shape the context in which their agency is embedded.

Our study focuses upon the case of Lancelot "Capability" Brown, a man who transformed his own social position and the English landscape, through which we examine how an actor's unfolding efforts to move from a social position at the periphery of a field, to a social position at the centre of a field, may present them with opportunities to influence field level change. To theorize about the reciprocal and inter-dependent relationship between social position and 
field level change, we draw on Bourdieu's (1977) Theory of Practice, and his unexplored notion of "position taking", which encompass the strategies and actions undertaken to adjust the balance of power in a field through changing one's social position (Bourdieu, 1993). Given the importance of time, we employ the historical method to explore the case of Lancelot "Capability" Brown. Our approach responds to longstanding and more recent calls for historical method to be employed in organization studies (see: Godfrey et al., 2016; Hoskin \& Macve, 1988; Kieser, 1994; Newton, 2010; Zald, 1993). The historic method is of particular value for its attention to context, examining events and conditions that give rise to specific opportunities, which enables us explore how agency is embedded in context (Wadhwani \& Jones, 2014). As such, we not only examine what actors do, but also account for changes in the wider field context, which provide opportunities for actors to enhance their social position and influence institutional change (David, Sine, \& Haveman, 2013).

\section{Conceptual framework: position taking and field level change}

Our research explores how agency for field level change is embedded in a social actor's context. With very few exceptions (e.g. Battilana et al., 2009; Lounsbury \& Crumley, 2007; Smets \& Jarzabkowski, 2013) extant scholarship continues to emphasise the purposive action of foresighted actors who envisage desirable institutional arrangements and pursue them through planned change (Smets \& Jarzabkowski, 2013). Such an approach assumes that opportunities exist, and are merely waiting to be discovered, however, such an account is increasingly challenged in the literature on entrepreneurship (see: Ardichvili, Cardozo, \& Ray, 2003; Sarasvathy, 2001). Given the contextual nature of agency, we suggest that the individual cannot be divorced from their context as opportunities are not merely discovered, but "are 'enacted' based on the entrepreneur's perception, interpretation, and understanding of environmental forces" (Dutta \& Crossan, 2005: 426). Moreover, as in entrepreneurship of 
all kinds, opportunity recognition in field level change is liable to require creativity, social networks and relevant prior knowledge and experience (Philips \& Tracey, 2007).

To examine how agency is intertwined with social position we draw on Bourdieu's Theory of Practice (1977). Conceptualising fields as systems of objective relations, Bourdieu highlights the potential for patterns of action, and interaction to become institutionalised as enduring social roles and rules. Although the system of objective relations may appear structured and structuring, it remains dynamic and in flux, played out by actors located in different social positions in terms of power and influence. Although Bourdieu allows for movement in social positions through his concept of "position taking", his conceptualisation of position taking is focused on explaining the reproduction of a field. For Bourdieu, actors generally position take in a non-conscious manner, i.e. they actively reproduce existing field level arrangements with no change to their social position. For an actor to engage in conscious position taking, the actor must have agency to either elevate their own social position, to enact field level change, and or a combination of the two. Conscious position taking constitutes a process of actions, with the aim of enhancing one's own capital endowments and/or diminishing other's capital endowments, thereby adjusting the balance of power in a field (Bourdieu, 1993). Capital "allows [the] possessors to wield a power, or influence" (Bourdieu \& Wacquant 1992: 98), and the degree of power relates to the volume of capital and the degree of valuation that capital enjoys within the field in question. In its basic sense, capital refers to some form of currency, power or endowment of resource that makes possible different actions and relations, with each field being characterised by different forms of currency, elaborated in terms of the main three different capital forms (economic, cultural and social).

Economic capital relates to the possession and control of financial capital, intellectual property, shares, and is that which is directly and immediately convertible into money 
(Bourdieu, 1986). Economic capital is institutionalised through property rights, and is commonly seen as a significant source of power.

Cultural capital comprises the knowledge, skills, tastes, preferences and possessions that give advantage (or disadvantage) in the system of relations (Bourdieu, 1986). These aspects of culture and knowledge can take different forms, from the aesthetics, tastes and ways of speaking acquired through socialisation, to the institutionalised knowledge and skills that are acquired through formal training and qualifications. Once acquired, these institutionalised forms of cultural capital also have symbolic potential to convey issues of reputation.

Social capital highlights the importance of the mutual relationships and acquaintances that reinforce or advance an actor's relative position of power within the field (Bourdieu, 1986), and includes interpersonal relationships and the resources embedded in those relationships (Burt, 1992). The three main dimensions of social capital are structural, relational and cognitive (Nahapiet \& Ghoshal, 1998). The structural dimension of social capital relates to an individual's network of contacts, which can be thought of as the density of relationships in a network, or the ability to span different networks. The relational dimension relates to the strength of a person's interpersonal exchange relationships. The cognitive dimension relates to understanding others' perspectives. Individuals, through repeated interactions, can develop strong relationships, a shared language and experiences, norms and sanctions, obligations and expectations.

In examining the interrelationships between the change in an actor's social position and field level change, it is important to explain how actors can enhance their own capital endowments by developing new capital, converting one form of capital into another, or using one form of capital to gain access to another. A potential important mechanism for doing so is symbolic capital, which Bourdieu defined in his later writings as "any property (any form of capital whether physical, economic, cultural or social) when it is perceived by social 
agents endowed with categories of perception which cause them to know it and to recognise it, to give it value." (Bourdieu, 1998: 47). The value of symbolic capital stems from honour, prestige or recognition (Bourdieu, 1984), which is developed through an actor's ability to manipulate symbolic resources such as language, writing and myth (Everett, 2002). As such, symbolic capital is an important source of influence in a field and represents the ultimate basis of power through which field participants impose their vision for a field on others (Meisenhelder, 1997).

\section{Data and method}

In this study we use a historiographical method, linking longitudinal and qualitative approaches (Ventresca \& Mohr, 2002), a method noted for its value in investigating the "how" and "why" questions of non-contemporary processes (Eisenhardt \& Graebner, 2007). The importance of history for understanding organizations has been affirmed by new institutionalists (Tolbert \& Zucker, 1983), yet despite this, there has been a tendency for a proliferation of ahistorical organizational research (Suddaby, Foster, \& Mills, 2014), with excursions of organization researchers into history noticeably rare (Kieser, 1994). This is unfortunate, as the ability of the historiographical method to explore the fine-grained details of change (Harrigan, 1983) may be particularly valuable in accounting for the complexity of institutional approaches. Jones and Khanna (2006) argue historical research is of particular value for the study of phenomena in which relationships between cause and outcomes emerge over long periods of time, enabling theories to be subjected to a much greater examination than when merely confronted with data on changes in the short-run, a quality of obvious benefit to organizational theorists.

The case of Lancelot “Capability” Brown 
The use of single case studies for the study of institutional change has been argued to be particularly effective where a deep, interpretive and holistic understanding of institutional change is required (Maguire \& Hardy, 2009; Suddaby \& Greenwood, 2005). Our study focuses on Capability Brown's shaping of the of the natural landscaping concept in England during the second half of the eighteenth century, a period during which there was profound transformation in the form of the landscape garden, from formal to natural, intertwined with a changing political, social and economic context. Whilst the first moves away from formality appeared modest, later changes became dramatic, and at times, ruthless. Everything in the new landscape had to appear natural; a bold shift away from French, Dutch and Italianate ornamental gardens, to a style that became synonymous with England. Lancelot Brown is held aloft as being responsible more than any other for influencing the nature of the transformation, although as our study reveals, the institutional change around landscaping pre-dated Brown's intervention. Brown came to count over half the House of Lords in the United Kingdom as his clients, undertaking over 170 commissions. Whilst Brown transformed the nobility's gardens, the ultimate impact of his work spread far wider. The gentry increasingly visited the great houses in the latter half of the eighteenth century and admirers who had sufficient land and financial resources returned home to begin landscaping projects of their own, trying to emulate the great houses and fuelling demand for landscape gardeners across the country (Hyams, 1971).

Brown was the son of a peasant farmer, and later one of his critics would accuse him of being a peasant emerging from the melon grounds and turning professor (Chambers, 1773: 13). Lord Chatham, a Prime Minister of the time, observed his meteoric rise to the extent he now "shares the private hours of [the King], dines familiarly with his neighbour of Sion [the Duke of Northumberland], and sits down at the tables of all the House of Lords" (Chatham, 1777). 


\section{INSERT FIGURE 1 ABOUT HERE}

Brown's ascent of the class system was not an act of chance. Rather, Brown's influence on the transformation of the British landscape was facilitated by a series of deliberate actions, designed to promote his status and power within the field, so that his social position was enhanced with cumulative impact upon his influence as a social actor in institutional change. Brown's actions and achievements, however, were not taken in isolation from the institutional environment of the time. Brown's success in shaping the new institution was the result of his 'capability' to recognise and carefully tap into the emerging social, political and cultural shifts of the period, which had already begun to influence landscape design.

\section{Data collection}

Our study employed historical methods-based practices (Farjoun, 2002; Passmore, 1958). Primary and secondary data sources were collected (Goodman \& Kruger, 1988), with the former involving access to archives throughout Britain, housing an array of primarily eighteenth century material, through which we were able to build a substantial archival residue (Gephart, 1993). We examined letters written to or from Brown during his lifetime (1716-1783), letters written about Brown and his work during his lifetime and the period immediately following (1716-1800), and letters concerning Brown's close landscaping contemporaries and alterations of the landscape (1700-1850). Letters were consulted from every known repository, including the British Library in London, county council archives, stately home archives and university archives. In addition to the collection of letters, we also consulted any surviving contracts between Brown and his clients, mainly deposited at county council and stately home archives. Further sources of primary data were found through the granting of access to examine Brown's surviving account book, housed at the RHS Lindley Library, coupled with records of Brown's original bank ledgers at Drummonds Bank, 
contained within the Royal Bank of Scotland Archive in Edinburgh. The secondary data we drew on encompassed biographies of Brown and his contemporaries, biographies of Brown's clients, analyses of Brown's landscapes and the landscapes of other garden designers, histories of change in landscape and art more generally, as well as the histories of the economic, social and political context of the period.

In a similar vein to other institutional studies (Greenwood et al., 2002; Rao, Monin \& Durand, 2003; Wright \& Zammuto, 2013), we constructed a chronology of the institutionalisation of the new landscaping form, utilising narrative and temporal bracketing to order the data (Langley, 1999). This resulted in a demarcation of three key stages: (1) Developing the concept of 'naturalness' (1739-1750), a period where Brown worked at Stowe gardens under William Kent's supervision, and formulated his ideas and skills for the creation of natural landscape gardens. (2) Taking the concept of 'naturalness' into an elite social network and the building of organizational capability to diffuse the new institution (1750-1764), a period in which Brown begins his independent practice, developing links with the aristocracy and moving from transforming sections of gardens to implementing complete natural landscapes. (3) Embedding the new 'natural' institution (1764-1783), a period characterised by Brown's social position being cemented within the country's elite and being awarded the position of King's Head Gardener. Brown becomes the accepted arbiter of good taste, structures his practice to undertake an increasing array of prominent commissions, and uses his elevated position to ensure a purer and unadulterated natural landscape is the established form.

\section{Data analysis}

Our analysis centres on the institutionalisation of the new "natural" style of landscape garden and those key to this change. First we focused on obtaining accurate data from contemporaneous sources, making an assessment of whether each item of data could be used 
to respond to the research questions (Goodman \& Kruger, 1988). Second, we validated the data using multiple sources of evidence. An evaluation of credibility was important as there were many cases of potential "hearsay" lacking a verifiable connection with Brown. Consistent with the principles of historical research, we favoured primary sources; gave a greater weight of credibility where there were multiple sources; and considered the existence of bias through comparing and contrasting sources with opposing sources (Gottschalk, 1969). Source criticism constitutes a key element of historical methodology and we sought to establish source validity, credibility, and expectations of source transparency. This process is "designed to allow researchers to understand not just what a source tells us about a development or topic of interest, but also the limits on relying on that particular source" (Kipping, Wadhwani and Bucheli, 2014: 316). We drew on the recommendations of Howell and Prevenier (2001), questioning to what extent was the author's report selective? What particular kinds of things would have interested this author? What may the author have been likely to ignore? What prejudices could have informed the account? For example, strong criticisms of Brown's landscaping were made by an individual then found to have contested an architectural commission against Brown earlier in his career, with Brown being the victor. We were then able to examine this source against a number of opposing primary sources, with an appreciation of the potential bias existing therein. Third, we organized the data into intermediate forms such as notes and tables and charts, synthesising and extracting the most relevant material. Finally, we separated evidence from interpretation whenever possible, reading history forward in constructing the narrative, and presenting the data to allow the reader to derive a chain of evidence (Farjoun, 2002).

Our analysis and interpretation of the data drew on the field of hermeneutics, an area of philosophy that deals with the theory and practice of interpretation (Palmer, 1969; Philips and Brown, 1993). Hermeneutic interpretation is particularly valuable when trying to overcome 
the significant challenges of examining fragmented and incomplete historical sources. The methodology seeks to interpret sources in the historical, social and cultural context in which they are produced and usually involves the analysis of a primary source in relationship to other sources that establish the context for its interpretation (Kipping et al., 2014). Whilst not always explicit, a hermeneutic approach has been used in numerous studies of organizations (cf. Hassard, 2012; Munir \& Philips, 2005). The hermeneutic approach is particularly relevant to the examination of how social actors shape institutional fields. Lueger et al (2005) note that most empirical studies of influence activities tend to dislocate the work of actors from the social context in which they operate, therefore creating an image of isolated and static episodes. However, the meaning of social actors' tactics in shaping insitutional fields may only emerge in relation to the social context it is embedded in, with hermeneutical analysis providing a useful methodology to overcome the existing dichotomy in research (Lueger et al., 2005). In implementing a hermeneutical approach, we continuously asked a critical question, adapted from the hermeneutical discussion of Lee (1991: 348), namely: 'how might we, as researchers belonging to a different time and culture from the writer of the text, proceed to interpret the text for the meanings originally planted in it?' In doing so we drew on the concept of the hermeneutical circle, searching for central themes in the texts and for thematic unity (examining how central themes are interrelated with broader arguments and related to patterns over time). The process was treated as one of discovery, moving from the part to the whole and vice versa, each time enriching the interpretations (Heracleous \& Barrett, 2001).

\section{Empirical analysis}

We now detail our case below in three periods. Period 1 (1739-1750) involves Brown position taking at Stowe, learning from Kent's ideas and applying them to sections of local stately home gardens. Period 2 (1750-1764) incorporates Brown position creating to form an 
independent business from which he concurrently manages projects of increased scale and involving a complete shift to the natural design. Period 3 (1764-1783) encompasses Brown position taking to become appointed as King's Gardener, from which we see him being able to refine the field, cutting artificial elements to achieve a purity in the new natural form.

\section{Period 1: position taking}

Context: The context in which Brown would take his early steps in landscaping had already been evolving for some time. The link between political ideology, landscape and building was much greater than it is today. Political landscape gardening emerged in the late seventeenth century as a way for courtiers and diplomats to assert their allegiance to a political ideology, yet discreet enough not to invoke a treasonous statement of position. Early supporters of William of Orange and eventually the Glorious Revolution of 1688, which saw William crowned King of Britain and Ireland, sometimes used their gardens as a way to establish distance between causes. In this case, a divergence between the Protestant outlook, which powerful Whig politicians saw positively as a less pretentious perspective, and the Catholic courts of Europe and indeed the King of England, James II, represented by baroque formality of design (Richardson, 2011). The prolific influence of the French style of landscaping, with rigid geometry, represented to many British politicians a visual incarnation of centralised, controlling power of absolute monarchy. A shift to aesthetics that possessed greater freedom could therefore sit more easily with philosophies that balanced the power of the monarchy with freedom, democracy and parliament (Barnatt \& Williamson, 2005; Malins, 1966).

Influential in the early stages of the shift from formal geometric designs to a more natural aesthetic was the designer William Kent. In the 1730s, Kent was landscaping Stowe gardens, the home of Lord Cobham, where he experimented with the natural style. Stowe was no ordinary stately home and garden. Under Lord Cobham, Stowe had become the capital seat of 
what has been called the Grand Whiggery, "the geographical and artistic centre of the cult of humane and political liberty" (Stroud, 1984: 30).

Social position: The fame of Kent's designs spread as it became known that he was at the forefront of landscaping ideas and the new natural design concept, and so it was in 1739 that a young Lancelot Brown made a bold move, leaving his Northumberland home and travelling south, with the aim of working at Stowe. Initially Brown had to settle for work close to Stowe until an opening materialised in Lord Cobham's staff. The position placed Brown under Kent's supervision, affording him the opportunity to become educated in the idea of naturalness. Building a high competence level and impression of potential, in less than two years, Brown had gained the trust and admiration of his employer, becoming Head Gardener in 1741, responsible for over 40 men (Stowe "Servants Wages", 1741).

Cultural capital: The politicisation of gardening and emblematic shift towards a more natural style, resulted in a period of changing cultural capital for actors involved in landscaping. This created an opportunity for those willing to align themselves with the emerging new form, of which Stowe was at the centre of development. In taking the position at Stowe and learning about the natural style, Brown started building his expertise by implementing Kent's designs. However, improvement of landscapes commonly involved some building work; for example, constructing bridges, grottos, temples or other small buildings. Brown developed these technical skills in addition to those in horticulture. There is evidence of Brown even copying out a fifteen-page glossary of terminology from The Builder's Dictionary: or, Gentleman and Architect's Companion (Bettesworth \& Hitch, 1734; Stroud, 1984). As such, rather than engage in formal education, Brown was an autodidact in developing his own capabilities. Lord Cobham's confidence in the skills and reliability of Brown was no doubt aided by the contrast with the less predictable nature of Kent, who would sometimes issue instructions, disappear for months and upon return "order without 
consulting his employers, three or four hundred pounds of work or more to be pull'd down, and then correct the plan" (Verney \& Abercrombie, 1926: 51). Brown's operational skills were the antithesis to Kent's erratic style, with letters showing him assiduously keeping his employer informed whenever Lord Cobham was away "An acct shall come on Tuesdays post all the work people have been employ'd and likewise the plan" (Brown, 1747). Brown had become immersed in Kent's principles and demonstrated an ability to execute them efficiently. This level of familiarity with the new natural concept instilled Brown with a cultural capital above that of a typical head gardener. Not only was he technically proficient in horticulture, he was acquiring a keen eye for taste and style in landscape design.

Social capital: Brown was adept at managing his interactions with his aristocratic employer, an example of which concerned the finishing of the head of the valley. Brown wrote to his employer's London home, suggesting they discuss the design further: "a summer's talk and tyrels about it may make it a very fine thing” (Brown, 1746). This familiar level of exchange was commonplace between Brown and Lord Cobham, yet was atypical for head gardeners of the time, who frequently complained of the lack of respect afforded to them by their employers. Brown's ability to manage his burgeoning relationship with Lord Cobham enabled him to amass an unusually high level of social capital with members of the elite. In this respect, Brown could take advantage of social changes in the first half of the eighteenth century that had resulted in a greater complexity of interrelationships within society. Unwritten codes of behaviour and status had begun to be adopted based on capital (often land), but also 'good taste', incorporating shared cultural views (Langford, 1989). Having a disproportionately high level of cultural capital given his position, therefore also contributed to the ease with which Brown's social capital could be accumulated. Brown's cultural capital, developed through his work with Kent, coupled with his relationship with his employer, opened up early opportunities for tentative first steps in influencing the field. In 
effect, Lord Cobham opened his address book and permitted Brown to undertake work for close friends and family. Such actions provided the basis for Brown to utilise Kent's natural landscaping ideas on whole sections of country house gardens.

Further opportunities for enhancing social capital were afforded by Stowe becoming the first garden in England to open to the public in 1744. Visitors and friends of Lord Cobham would sometimes be given a tour by Brown, providing time to "show-off" his cultural awareness, skilfully beguiling the gentry with his commentary on the natural landscaping taste. Sanderson Miller, a gentleman architect, spent five hours walking in the gardens with Brown, then bestowing further opportunities for Brown to extend his social connections by recommending him to the Earl of Coventry at Croome, Sir James Dashwood at Kirklington Park, Lord Dacre at Behus and Lord Brooke at Warwick Castle (Miller, 1749-1750; Dacre, 1756; Hawkes, 2005; Jacques, 1978). Within a short period, Brown's social capital had developed to an extent that was not just rare for a head gardener, but unique for the position in the field.

Symbolic capital: The cultural capital of working with Kent on natural designs at the country's leading gardens, coupled with the social capital of being so closely connected to Lord Cobham, provided a unique opportunity for Brown. It resulted in a range of local landscaping projects whilst still Head Gardener at Stowe. These gave Brown the chance to show he was capable to implement the natural scheme without Kent and enabled his name to become familiar to the elite, with letters between aristocrats making favourable comments as to Brown's skill and good taste. Indeed it was perhaps unlikely that anyone tutored by Kent and so highly regarded by Cobham, would not take on a symbolism for possessing the utmost levels of good taste. Word quickly spread, with even Walpole, Whig politician and son of the former Prime Minister, reporting on Brown's section of landscaping at Warwick Castle, noting "one sees what the prevalence of good taste does" (Walpole, 1840: 399). Such 
accolades were particularly pertinent during a period when society "debated the subject of taste more perhaps than any comparable group of people before or since" (Clifford, 1966: 157). The increasing symbolic capital afforded an additional benefit. Brown's early commissions show a very high level of on-site supervision, and his payments, shown in Drummonds bank ledgers, similarly displaying a repetition associated with continual input. As Brown's symbolic capital increased as the man capable of converting a landscape to the new natural style, thus conveying good taste to the recipient, it became less necessary to be undertaking the laborious regular site work. Brown had developed sufficient symbolic capital so that as long as he was the designer and overall supervisor, the client was content for a foreman to implement the design (Drummonds Bank, 1753). This freed Brown to focus on building more contacts and bigger and more prestigious commissions, respectively enhancing his social and cultural capital further and enabling more opportunities to spread and shape the natural landscapes across the field, as we see in period 2.

Outcome: Brown was seizing opportunities to convert sections of gardens to the natural style. These early steps in shaping the field showcased the natural landscape design in much larger proportions than in Kent's work. However, the natural designs also had to include a plethora of garden buildings and political statues at the request of clients. Such features were a regular occurrence in the plans and letters concerning Brown's early work, meaning that interspersed amongst the natural aesthetic stood completely artificial elements (Brown, 1746; Grenville Agreement Book, 1742; Newnham Paddox Building Record, 1743). In this period, Brown's approach towards a more natural landscape was not entirely accepted by clients.

Brown could easily have remained in a head gardener's position as was the norm in what was generally a role of long tenure. However, this was a position without opportunities for further advancement. Whilst Brown's social and cultural capital were atypical of the role, the social position of a head gardener for a country estate would always be intrinsically limited. 
Brown utilised his amassed cultural, social, and symbolic capital in a new position with greater potential for social elevation and opportunities to take the concept of naturalness to more of the aristocracy. Brown risked setting up an independent practice.

For Brown to take the concept of naturalness to more of the elite required that he shift to a more central social position in the field. In Period 2, we see Brown engaging in position creating, taking a new role and making more pronounced efforts to enhance his social position, building upon the cultural, social, and symbolic capital accumulated within Period 1.

\section{Period 2: position creating}

Context: Social boundaries, based on the old court hierarchies, were receding. Great aristocrats and courtiers were beginning to play down the divisions between themselves and other propertied society. As barriers eroded, a more singular class of upper society emerged, consisting of significant landowners and the local gentry, becoming known as 'polite society', essentially those who owned and ran the country (Williamson, 1995: 110). Such changes were partly facilitated by the expansion of the economy and recovery of the fortunes of the local gentry. The relaxed style of the natural landscape mirrored the easier pattern of social relationships and was attainable to a significant number of landowners within the group. In other ways, however, the landscape garden helped emphasise divisions between polite society and those further down the class system. The landscape garden was unobtainable to those in the broad mass of the middle class, who lacked the necessary land and financial resources. In this respect, the landscape garden helped distinguish the gentry and upper bourgeoisie from the rest of society, providing a clear representation of social status (Williamson, 1995). The political and social changes, coupled with the striking visual demonstrations of the new style as exemplified at Stowe, ensured the new style was increasingly associated with good taste. A demand was emerging that Brown, with his existing cultural capital and social capital, was 
well placed to take advantage of. Brown now had both the technical expertise, and range of contacts, to capitalise on the opportunity and enhance his social position further.

Social position: Around 1750 Brown moved south to set up an independent practice in Hammersmith, regarded as a commercial centre of 'polite society'. This reflected Brown's ambition, as most Head Gardeners chose the safety of remaining employed by others (Musgrave, 2014). It also opened up opportunities for social advancement as an independent landscape designer (or improver as the role was commonly known) tended to be treated with a higher level of respect and gentlemanliness (Johnson \& Hogg, 1864). In this new position, Brown had the freedom to utilise the symbolic capital he'd amassed from his early reputational distinctions to build new social connections and take on a much larger array of prestigious projects that would in turn enhance his cultural capital. His status could be increased, enabling opportunities to take the work of Kent to a new level, shaping the new form as it spread.

Cultural capital: Already possessing the conceptual and technical capabilities to implement the natural landscape style, Brown developed his business credentials and modus operandi for taking clients from expressions of interest, to a transformed landscape. Upon being asked to visit, Brown would assess the landscape for its intrinsic capabilities. Intrinsic capabilities referred to the potential for conversion to the natural style and Brown presented himself as the arbiter who could evaluate this given his cultural capital (Tyne \& Wear County Council Museums, 1983: 9). This was a bold assertion for an independent businessman at a time when the largest landowners considered themselves the gatekeepers of cultural appreciation (Goring, 2008). Owners felt their land was being examined for sufficient natural beauty lying dormant that, given significant alterations, could be revealed. This assessment would result in the owner being told that their land indeed had capabilities. We are not aware of any occasion when Brown proclaimed an aristocrat's land lacked the necessary capabilities. This would not 
have helped Brown's establishment with the elite, nor his bank balance. The process emboldened the client's opinion that Brown was indeed a man of the upmost cultural prowess, able to spot a landscape which could be peeled away to uncover a scene fit to rival those at the forefront of good taste. Clients would then commission the drawing of plans and Brown would return with designs for consideration (Brown, 1753). Brown would draw up a contract, or a series of contracts, detailing work to be completed at each stage and the regularity of payments (Brown 1754). The majority of letters exchanged about Brown's work were in adulation at his ability to create a natural aesthetic, although occasionally the effect he desired was not always immediately achieved. Admiral Lord Anson employed Brown at Moor Park from 1753. Horace Walpole visited soon after and commented that for the $£ 6,000$ paid, "he [Brown] has undulated the horizon in so many artificial mole-hills that is full as unnatural as if it was drawn with a rule and compasses" (Walpole, 1857: 324). However, such criticism appeared a rarity, with Brown's reputation growing quickly, each new commission standing as a testimony to his cultural capital for executing the concept of naturalness. The number and geographical spread of the commissions increased rapidly, facilitated by an increasing reliance on foremen to manage the implementation of the projects. This was enabling Brown to operate sometimes with just twice-yearly on-site visits and therefore greatly expanded the spread of his work on the field.

Social capital: Landowners were keen to share the joys of their new vista with fellow stately home owners. In 1757 a letter from the Earl of Breadalbane described the transformation of the landscape from "disagreeable and bad" to "beautiful and grand" (Breadalbane, 1757). Brown was at ease when dealing with members of the aristocracy, adept at navigating the fine line of flattery (in relation to the intrinsic capabilities of their estates) without subservience. After visiting Bowood in 1761, the Earl of Shelburne wrote: "He [Brown] passed two days with me... and twenty times assured me that he does not know a 
finer place in England than Bowood Park" (Fitzmaurice, 1761). Whilst independent businessmen of the period could expect some level of respect and courtesy, the reverence Brown was shown was becoming far beyond the norm. Letters exhibited a remarkable degree of familiarity and the quantity of projects being accumulated was starting to represent a network of considerable density.

From examining known clients of Brown, our data shows that around half came from the nobility. Having over 80 clients from the nobility was a very high number given that the House of Lords had just 157 adult and conforming peers in 1760 (Jones \& Jones, 1986). Of those clients outside the nobility, almost one-third possessed knighthoods. Of Brown's clients, our data reveals 55 percent were in the Whig party (the largest landowners), 20 percent Tory, and 25 percent were either non-partisan or unidentifiable.

Symbolic capital: The nobility Brown visited wanted to hear that their land had the potential to be converted to the new natural style and it became a habit for Brown to announce to the landowner that his estate had "capabilities for improvement" (Garrick, 1757; Lisburne, 1772; Smith, 1788). So often did Brown pronounce this that Lancelot Brown became known as Capability Brown. Capability Brown became a brand name, or in Bourdieu's terms, symbolic capital (Bourdieu, 1977), which was now associated with the pinnacle of good taste. Brown's developing fame is evidenced through the playwright David Garrick inserting a joke about Brown into one of his plays, announcing the "capabilities" of the Elysian Fields, suggesting the potential for improvement in the resting place and paradise for the heroic and virtuous in Greek mythology (Garrick, 1757). Brown's symbolic capital was now such that clients clamoured for his attention, unperturbed by the fact that they would only likely see him on site once or twice per year, his foremen handling all operations. In 1753, not long after his establishment in independent practice Brown was making regular 
payments to four foremen, yet by 1760 this had risen to regular disbursements to around twenty (Drummonds Bank,1753-1783).

Outcome: By creating a position in independent practice, Brown had been able to significantly build upon the cultural, social and symbolic capital he'd developed at Stowe and locally-based commissions. Brown was becoming famous, regarded as a possessor and facilitator of good taste. The Earl of Shelburne wrote to his son "what wou'd you give me to know the consequences of the visit of the famous Mr Brown" (Shelburne, 1757). He was now able to take Kent's creativity in natural design and apply it to much larger areas. Whole landscapes were now being converted to the natural style often working over a mile from the house, rather than just constructing additions to, or segments of, wider geometric gardens that were a hallmark of his designs in period 1 (Trentham, 1759). During this period, Brown's maps show an increasing use of perimeter belts of trees, separating the park from views beyond and further ensuring the only vistas were of naturalism (Lowther, 1763). Not just riding the wave of change to a more natural aesthetic, Brown was now driving it. His social, cultural, and symbolic capital being such that he was trusted with shaping the nature of the new institution.

Over time, members of the aristocracy were treating Brown with greater respect and equality than would be expected of someone of his class and position. Brown's amassed capital ensured that he was the person the elite would go to in order to see if they possessed (or could possess) the height of good taste. His social connections were powerful, spread across many of the wealthiest landowners, whose letters of respect and invitation had to be continually diverted between country estates to catch up with his progress. Brown's accumulated capital was now significantly higher than his social position as an independent businessman. The respect he commanded from the elite did not mean that he was part of the 
elite. Nor could this be achieved in his current position. An attempt was made to elevate his social position further.

\section{Period 3: position appointed}

Context: There was now no doubt that the new landscaping style had taken hold, with irrevocable changes being made to the gardens of the elite across the country. Good taste was now inextricably bound with the natural style. Brown's ability to apply the natural style to increasingly large areas was also facilitated by the characteristics of the period in which he operated. The enclosure movement of the eighteenth century had gained rapid momentum in the 1760 s, involved the removal of communal rights, controls, or ownership over a piece of land. Enclosures enabled the owner's total control of a vast acreage, which could then be used for grand designs (Malins, 1966; Kain, Chapman, \& Oliver, 2004).

Social position: Still an independent businessman, albeit one of very high regard, for Brown to take a more elevated social position with greater equality amongst the elite, he would require a change in role. The elite usually held offices of trust, serving the King or government. To overcome this disparity, Brown orchestrated a petition to become Royal Gardener, a position that would give him twice weekly audiences with the King, and command over his majesty's gardens. The petition included two Dukes and eleven others peers in 1758 (Brown, 1758). The bid failed. Whilst Brown's social capital was considerable, it did not yet extend to those charged with making appointments to the position of King's Master Gardener. It was a frustrating outcome. Brown clearly had easy access to many of the elite, yet his position as a businessman didn't make him one of them. George Lucy of Charlecote Park, where Brown already had a contract for landscaping work, found the scenario a bit confusing. His visit to Bath coincided with one of Brown's trips. Lucy wrote that Brown had called upon him, "not on business, as he said, but to enquire after my 
health...I did not know well how to construe his visit" (Lucy, 1761). Brown's social capital wasn't matching his social position, creating a uneasy tension.

Social capital: In 1764 another attempt was made to become the King's Master Gardener. One of Brown's original petitioners, Lord Cobham's nephew, George Grenville, had recently become Prime Minister. This was highly fortunate and Brown capitalised on it. Brown met with Grenville in June 1764, but chose not to mention his desire till after, penning a letter on the $22^{\text {nd }}$ of June "I would have made the request when I had the honour of seeing you...but my courage failed me...I should be happy to have the garden at Windsor Castle...I know you will do it if you think it is proper but, if it is not, I do not desire it" (Brown, 1764a). The following month Brown's appointment commenced as the King's Master Gardener (Brown, 1764-1783).

Cultural capital: Facilitated by the elevated status, Brown consistently took on a new group of major projects every year, keeping pace with the enquiries. Within a year he had taken on two surveyors, John Spyers and Samuel Lapidge to help manage the additional demand.

A contract to landscape Blenheim Palace for the new Duke of Marlborough in 1764 was a particularly significant endorsement. Brown had become an arbiter of good taste for the aristocracy, a reflection of his valuable cultural capital and the honour and prestige the aristocracy bestowed on him. The scale of the project was colossal, with payments over a decade amounting to over $£ 21,500$ (Brown, Account Book). With his usual formula, Brown destroyed the formal gardens to create his natural scene. In doing so, Brown was creating templates for those further down the landscaping hierarchy to follow, individuals primarily operating on a smaller scale and more regionally based (Repton \& Loudon, 1840).

Implementing so many projects concurrently was not without its problems. For projects such as Blenheim, Brown called upon his most trusted foremen, individuals appearing 
consistently in his accounts over a long period (Brown, 1765). However, at other sites there are instances where Brown is required to correct errors. Nearly all of these end with satisfactory resolution, although an exception to this related to work for Sir John Griffin at Audley End. Here there was substantial delay and Brown's foreman managed to curve the whole river in the wrong direction from that detailed in Brown's plans, causing disagreements over the quality of work and payments (Brown, 1762). Most errors were not of such magnitude and did not appear to dent Brown's cultural capital, with clients seemingly acceptant that some mistakes would be made during major earthworks to shift to the new style. Indeed, Brown was quite open about the troubles, exchanging letters with one client "when I am galloping in one part of the world, my men are making blunders and neglects" (Bruce, 1765).

Symbolic capital: Ironically, the managerial duties associated with being the King's Master Gardener seemed to offer little interest to Brown, who was frequently absent from the Royal Gardens, although careful to be back in time for his meetings with the King. This was not without risk as on one occasion Brown's assistant hastily wrote to say that His Majesty had made an unannounced visit when Brown was away. The King had agreed to return the following Saturday, but had instructed him not to inform Brown. Fortunately the foreman sent Brown advance warning (Brown, 2011). There also appeared letters from the Clerk Itinerant to the Board of Works stating the gardens were not in so good a condition as they ought to be. This angered Brown who wrote back chastising him for the lack of respect (Brown, 1770). Similarly, the annual wage of $£ 2,000$ (Brown, 1764-1783), which for many would have been a small fortune, was in Brown's realm not exorbitant in contrast to his other income. It was the symbolism of the position that was attractive and the social position that it offered. Brown's letters and contracts in the period following his raised social position see him portraying himself more as an artist than landscape designer or businessman. This 
echoed the characteristics of those in the highest echelons of society, who, whatever their commercial involvement, tended to prefer talk of 'taste' rather than 'trade' (Olsen, 2017). A contract to finish the Valley of Roche Abbey, even made reference to the work being undertaken "with Poet's feeling and with Painter's Eye" (Brown, 1774). After spending two hours with Brown in the grounds of Wimpole Hall, Marchioness Grey wrote in a letter "[Brown's] wand has raised such landscapes to the eye...his touch has brought them out with the same effect as a painter's pencil upon canvas" (Grey, 1769). In expounding his landscape vision, Brown adapted his rhetoric according to the audience. In addition to referring to his skills as being akin to those of a poet or painter, he also made comparisons to that of a writer, as exemplified in his interactions with Hannah More, a writer herself, to whom he compared his work to literature:

"Now there" said he, pointing his finger, "I make a comma, and there" pointing to another spot, "where a more decided turn is proper, I make a colon; at another part, where an interruption is desirable to break the view, a parenthesis; now a full stop, and then I begin another subject." (Roberts \& More, 1835: 267)

The shift from mere landscape improver and businessman to artist and fellow member of the elite appeared to be accepted. Lord Coventry commented "I certainly held him very high as an artist, and esteemed him as a most sincere friend" (Hodgson \& Hodgson-Hinde, 1827: 245).

To match his elevated social position, Brown became Lord of the Manor himself, purchasing an estate (Fenstanton Manor) from the Earl of Northampton, further adding to his symbolic capital and sealing his embeddedness in the social elite (Brown, 1767). The symbolism and transfer of capital involved in the exchange was not lost on the Earl, who wrote on the transfer deed "I take the Manor of Fen Standon to belong to Lawrence Brown Taste Esq., who gave Lord Northamptonshire taste in exchange for it”, referring to Brown's landscaping work on the Earl's estate (Tyne \& Wear County Council Museums, 1983: 35). 
Outcome: Brown's interactions with the elite now had a much greater air of equality. Walpole, a keen supporter of Brown, had observed the interactions with the nobility and wrote in a letter "The first peer that experiences it, laughs to conceal his being angry at the freedom: the next flatters him for fear of being treated familiarly; and ten more bear it because it is so like Brown." (Walpole, 1848: 87). Whilst Brown's capital had risen to be more akin to those of a higher social position, only through taking steps to become appointed to the role of the King's Master Gardener did he enter the elite. Brown's social position and influence ensured he was now a man to which considerable deference must be paid, enabling him to hold greater sway over the aesthetics in refining the institution. The new landscape style was now firmly institutionalised, but in a mould shaped by Brown. Where he could not impose his desired aesthetic, he was content to refuse the work, regardless of the income lost. Brown's symbolic capital within the field, boosted by his appointment to be King's Royal Gardener, meant that such refusals could cause substantial embarrassment for aristocrats. For example, sent for by a very wealthy gentleman in Staffordshire, Brown instructed which hills should be clumped with trees. The client replied that it was another landowner, Mr Jennings, who owned the distant hills referred to. Brown then suggested which valleys should be cleared and floated, to which the client responded that a valley in question was also possessed by Mr Jennings. At this point Brown retorted "I think Mr Jennings should have sent for me, not you" and refused to undertake any design work (Morning Post, July 30 1774).

A letter from Lord Bruce to Brown obediently stated "we shall scarce venture to go a step further to complete it without your advice upon the spot" (Bruce, 1772). Brown was now in a position to impose his preferred landscape design, one of greater purity, without unnecessary buildings nor political statues and statements that his clients had frequently demanded in his early works. Whilst in period 1, Brown's designs were littered with garden 
buildings, by period 2 plans typically showed just three or four. In period 3 maps rarely have more than one or two structures, and frequently none at all except for sham bridges that disguised the retaining walls to dams. The aristocracy were now virtually completely obedient to his word, but on the few occasions a client insisted on preventing an existing building or geometric feature from being destroyed, Brown would either move it much further away or hide it with land contouring. The natural aesthetic took priority.

Brown's social position within the networks of the aristocracy was now central, even acting as an intermediary between Lord Bute and the Prime Minister, William Pitt (Lord Chatham), who spoke of Brown as "deserving of the regard shown to him....an honest man, and of sentiments much above his birth." The Prime Minister allowed Brown to act as a gobetween himself and the King following a fall-out, reporting back to Lady Chatham "Today, and indeed many opportunities have occurred of late, in which I have had very favourable conversations [with the King]...I was told that Lord Chatham was perfectly restored" (Pitt, 1840: 430).

Through his enhanced social position and appurtenance to changes in the political, social and cultural environment of the time, Brown had carefully taken the pre-existing ideas and receptive context for the new institution. He had then replicated, expanded and, as his social position increased, ultimately shaped the elements to imprint a complete and pure natural landscape on the elite gardens of England. Brown's social, cultural, and symbolic capital built upon and reinforced one-another, with frequent conversions between the different forms of mutually dependent capital forms. Increases to Brown's social and cultural capital in period 1 were converted through symbolic capital to enable an enhanced social position in independent practice. Similarly, period 2 saw Brown's now high levels of social and cultural capital converted to an elevated level of symbolic capital through the 'Capability' brand, which in turn stimulated further waves of social and cultural capital to the extent that it 
enabled an attempt to move to an elite position in period 3, with cumulatively enhanced powers to refine the field.

As an epitaph, upon Brown's death in 1783, even the King could not help a light jest at the control Brown had commanded over the aesthetic, saying to under-gardener Michael Milliken, "Brown is dead. Mellicant $[s i c]$ you and I can do here what we please" (Keppel, 1852: 216).

\section{Discussion}

Rather than being "unleashed actors" (Powell \& Colyvas, 2008: 277), our study provides insight into the structural conditions in a field that produce opportunities, and how a positionally-disadvantaged social actor takes advantage of those opportunities (Fligstein, 2001, 2013; Fligstein \& McAdam, 2011). Heeding the call for the greater use of history by new institutionalists, we employed a historical method to examine the case of Capability Brown (see: Suddaby et al., 2014) to examine our broader theoretical concern. Our aim has been to generate new insights into the understanding of how an individual engages in the process of field-level change, focusing on the relationship between the individual agent and the change enacted. In doing so, we focus on the transitioning of an actor's social position over time as a key factor in institutional change, which has been absent in extant scholarship.

Focusing on the flow of agency over time, we move away from the concept of "heroic" social actors, battling against the status quo, to examine how actors work with the fluidity in a field to bring about the change they desire. In doing so, rather than merely "position taking" from a fixed menu of social positions in a field, we provide insight into how actors are able to use changes to create new opportunities for themselves to enhance their own social positions as an important element in shaping field-level change. Bourdieu allows for the movement of social positions through his concept of position taking, yet his conceptualisation of position taking is focused on explaining the reproduction of a field. Hence, for Bourdieu, actors 
generally "position take" in a non-conscious manner (Bourdieu, 1993). We suggest that position taking does not have to be non-conscious, and that actors may be conscious and agentic in position taking as opportunities arise in a field. As we detail next, context and agency are not static.

Capability Brown started his career at the periphery of the field (with minimal economic, cultural and social capital), which in institutional terms would have provided him with the potential motivation for institutional change (Maguire et al., 2004), but no power to do so at a time when social mobility was limited (Stone \& Stone, 1986). Brown was fortunate, however, in that the field-level context in which his career unfolded was one in which the landscape was becoming politicised, with the shift to a more natural approach, being wrapped up with broader movements within politics, literature and the arts emerging from the Glorious Revolution of 1688. Hence, Brown's agency is shaped not just by pre-existing institutional arrangements, but also by proto-institutions emerging in the wider field to which he was able to align (Harvey, Press \& Maclean, 2011). The case of Brown demonstrates the importance of understanding the structural context within which any agency is enacted, and how fluidity in the field may create opportunities and shape agency over time. We suggest, therefore, that studies of field level change need to attend to the fluidity of context, and its potential to shape agency, which points to the importance of situating actors in the flow of history to be able to reveal further insights into the dynamics of change (Godfrey et at. 2016; Wadhwani \& Jones, 2014).

Clearly, Brown's ascent is unusual given the lack of social mobility in the eighteenth century. Notwithstanding his voracious appetite for work, Brown was keen to step into challenging situations, which required him to develop his own capabilities. The move to Stowe was one of position taking, an agentic act, yet one that was materialised through the opportunities afforded by the exogenous changing nature of the field. At Stowe, in terms of 
his social position, Brown developed his cultural capital as being the person who was able to match the artistic with the practical, and in doing so became indispensable to Lord Cobham. In Brown's relationship with Lord Cobham, however, it was not only his capability in landscaping that was important, it was his ability to manage his interactions that enabled him to develop valuable social capital. Over time, an inconsistency emerged between Brown's level of social and cultural capital and that which was the norm for a role as head gardener. The inconsistency, allied to the fluidity of the field, promoted Brown's agency to change his social position in order to be able to exploit the potential opportunities that lay beyond his role at Stowe, and which could further elevate his social and cultural capital, and with them the chance to make a much larger impact on the field. Hence, actors' agency will be shaped by the juxtaposition of their social position to their capital endowments. If capital endowments exceed social position, then this may act as a catalyst to promote an actor's agency (see: Mouzelis, 1995).

Brown decided to "position create", setting up in independent practice at the heart of polite society. In this second period, we see an interaction between Brown's cultural and social capital as he developed his own social position over time. In terms of position taking strategies, both forms of capital have a mutually reinforcing effect on one another with respect to their accumulation, which is interesting and a development of Bourdieu's (1986) idea that one form of capital may be converted into another. Bourdieu focused on the transformation of economic capital into other forms of capital, viewing economic capital to be at the root of the other forms. The case of Brown demonstrates how different forms of capital may be developed in a symbiotic manner, with a specific focus on cultural, social, and symbolic capital.

The process through which Brown's capital forms were mutually reinforcing, and transforming, requires more explanation. The symbolism of "capability" of the land is 
important as it enabled Brown to link his vision of naturalness to the inherent capabilities of the landscape. Brown was careful in communicating that his own capabilities were merely a mechanism through which the inherent capability of the landscape (in the past) could be transformed through his work (in the present) to return the landscape to its former natural glory (in the future). Rather than presenting himself as a revolutionary, seeking to impose a new form, he presented himself as the person who was able to return England to its former natural glory. His symbolic capital is encapsulated in his moniker "Capability", which was important in being able to position himself alongside the aristocracy as a man who was there on the basis of distinction of what he could do for them. Hence, we suggest that the value of an actor's capital endowments derives from their ability to shape symbolic capital, which influences how other actors interpret their social position, and associated underlying capital endowments. Rather than being an actor challenging the existing social order, Brown positioned himself and the institution of naturalness, as symbolically aligned with the interests of the aristocracy.

Finally, and returning to the importance of appreciating the fluidity of a field, we highlight how changes in the field may enhance the value of an actor's capital endowments over time, above and beyond the effects of their agentic work. Not only were Protestant ethics taking hold, the political context was receptive to the diffusion of the institution of the natural landscape. As the new form took hold in England (and eventually beyond England) (Olin, 2012), Brown's capital endowments became more valuable, and thereby his influence over the field; i.e. the diffusion of the institution and capital endowments interacted in a recursive manner. Brown was now treated by the aristocracy with a level of respect and equality far out of line with that afforded to the social position of an independent business owner of the time. As before, this prompted efforts to enter the social elite who tended to hold positions of service to government or King. Drawing upon his relationship with the new Prime Minister 
enabled Brown to be "position appointed", becoming the Royal Gardener, a role affirming his centrality to the field, and also an elevated and highly privileged social position. In his new role, Brown presented himself more as an artist, a creator of good "taste" rather than "trade". His envelopment into the aristocracy was also symbolically helped through his purchase of a country estate, becoming "Lord of the Manor" himself. From his central position to the field, Brown's influence over the nature of landscaping across the nobility was assured, stripping away the artificial adornments that had often been a feature of his earlier work at the behest of clients, to create pure and bold natural landscapes, imprinting an indelible stamp on the institution.

\section{Conclusion}

Our study provides insight into social actors' tactics in shaping fields (Fligstein, 2001), with particular attention on how an actor's work to promote field level change, both shapes and is shaped by, their location in the field (Battilana, 2006, 2011; Lockett et al., 2014). Employing Bourdieu's (1977) Theory of Practice, and the under explored notion of "position taking" (Bourdieu, 1993), our empirical study highlights how an individual may engage in the process of institutional change, not from the periphery of a field, nor from an existing central field position, but through shifting their social position as they move from periphery to core over time. Our study emphasises an actor's work to shape change, and position-taking to enhance social position, cannot be treated in isolation, and that position-taking strategies should be viewed as a core component of the work of social actors in trying to influence institutional change. Further, our study suggests tensions between an agent's accumulated capital and the social position typically afforded to their role in the field, may lead to efforts to "take" or "create" new positions, providing opportunities to influence the developing institution. 
We recognise that our research looks at a specific historical case and therefore opportunities exist for examining the interactions between social position, capital, positiontaking strategies and institutional change in a variety of settings. Such work may provide further insight into the dynamics of these relationships in different contexts. In addition, we focus on a case where an individual's position-taking strategies result in the elevation of social position and an ability to influence the shape of the evolving institution. However, cases where position-taking strategies fail are also of interest, providing insight into the hallmarks of attempts to elevate social position that are unsuccessful, whether due to their inability to shift to a new position, or failure to convert an elevated position to provide meaningful influence on the developing institution.

\section{Funding}

This research received no specific grant from any funding agency in the public, commercial, or not-for-profit sectors. 


\section{References}

Ardichvili A, Cardozo R and Ray S (2003) A theory of entrepreneurial opportunity identification and development. Journal of Business Venturing 18(1): 105-123.

Battilana J (2006) Agency and institutions: The enabling role of individuals. Organization 13(5): $653-676$.

Battilana J (2011) The enabling role of social position in diverging from the institutional status quo: Evidence from the U.K. National Health Service. Organization Science 22(4): $817-834$.

Battilana J, Leca B and Boxenbaum E (2009) How actors change institutions: Towards a theory of institutional entrepreneurship. Academy of Management Annals 3(1): 65-107.

Barnatt J and Williamson T (2005) Chatsworth: A Landscape History. UK: Windgather Press.

Bettesworth A and Hitch C (1734) The Builder's Dictionary: or, Gentleman and Architect's Companion. London: Bettesworth \& Hitch.

Bourdieu P (1977) Outline of a Theory of Practice. Cambridge: Cambridge University Press.

Bourdieu P (1984) Distinction: A Social Critique of the Judgement of Taste. London: Routledge.

Bourdieu P (1986) The forms of capital. In: Richardson JG (ed) Handbook of Theory and Research for the Sociology of Education. New York: Greenwood Press, 241-258.

Bourdieu P (1993) The Field of Cultural Production: Essays on Art and Literature. London: Polity Press.

Bourdieu P (1993a) Sociology in Question, trans. Richard Nice. London: Sage.

Bourdieu P (1998) Practical Reason: On the Theory of Action. Stanford: Stanford University Press. 
Bourdieu P and Wacquant L (1992) An Invitation to Reflexive Sociology. Chicago: University of Chicago Press.

Breadalbane J (1757) Letter from the Earl of Breadalbane. (MS WIL/C2/17). Willis Papers, Durham University.

Brown J (2011) The Omnipotent Magician: Lancelot 'Capability’ Brown, 1716-1783.

London: Random House.

Brown L (1741) Letter from Lancelot Brown to Lord Cobham (MS SJSM). Stroud Papers, Soane Museum Archives, London.

Brown L (1746) Letter from Lancelot Brown to Lord Cobham. (MS WIL/C5/2/1). Willis Papers, Durham University.

Brown L (1747) Letter from Lancelot Brown to Lord Cobham. (MS WIL/C5/2/2). Willis Papers, Durham University.

Brown L (1753) Contracts relating to work at Petworth House. (MF1185). Petworth House Archives, West Sussex County Council.

Brown L (1754) Contracts relating to work at Petworth House. (MF1185). Petworth House Archives, West Sussex County Council.

Brown L (1758) Petition for Royal Gardener. (MS SJSM). Stroud Papers, Soane Museum Archives, London.

Brown L (1762) Correspondence with John Griffin. (MS D/DBy A365). Essex Record Office.

Brown L (1764a) Letter written by Lancelot Brown to George Grenville. (MS 57822-57828, f.155). Grenville Papers, The British Library, London.

Brown L (1764-1783) Lancelot Brown account book. RHS Lindley Library, London.

Brown L (1765) Brown's account ledgers. Drummonds Bank. RBS Archives, Edinburgh. 
Brown L (1767) Letter written by Lancelot Brown to the Earl of Northampton. (MS

FD1118). Castle Ashby, Northamptonshire.

Brown L (1770) Letter written by Lancelot Brown to William Robinson. (MS: PRO1/4-89-

87). Chatham Correspondence. The National Archives, Kew.

Brown L (1774) Articles of work for Sandbeck and Roche Abbey. (MS 1001161). English Heritage register of historic parks and gardens. English Heritage, London.

Bruce T (1765) Letter from Lancelot Brown to Lord Bruce (MS 9/35/52).

Bruce T (1772) Letter from Lord Bruce to Lancelot Brown (MS 30725). Brudenell-Bruce

Papers, Swindon and Wiltshire Record Office, Wiltshire.

Burt R (1992) Structural Holes. Cambridge, MA: Harvard University Press.

Chambers W (1773) A Dissertation on Oriental Gardening. London: W. Griffin.

Chatham W (1777) Letter from Lord Chatham to Lady Stanhope. (MS PEO30/8). Chatham

Correspondence, National Archives, London.

Clifford DP (1966) A History of Garden Design. London: Faber and Faber.

Dacre T (1756) Letter from Lord Dacre (125B/473). Essex Record Office, Essex.

David RJ, Sine WD and Haveman HA (2013) Seizing opportunity in emerging fields: How institutional entrepreneurs legitimated the professional form of management consultancy. Organization Science 24(2): 356-377.

Drummonds Bank (1753-1783) Lancelot Brown Account Ledgers. Edinburgh: RBS Archives.

Dutta DK and Crossan MM (2005) The nature of entrepreneurial opportunities:

Understanding the process using the 4 I organizational learning framework. Entrepreneurship: Theory and Practice 29(4): 425-49.

Eisenhardt K \&and Graebner M (2007) Theory building from cases: Opportunities and challenges. Academy of Management Journal 50(1): 25-32. 
Everett J (2002) Organizational research and the praxeology of Pierre Bourdieu.

Organizational Research Methods 5(1): 56 - 80.

Farjoun M (2002) The dialectics of institutional development in emerging and turbulent

fields: The history of pricing conventions in the on-line database industry. Academy of Management Journal 45(5): 848-874.

Fitzmaurice J (1761) Letter from Lord Shelbourne to his Son. Wiltshire Archaeological and Natural History Magazine 42: 19.

Fligstein N (1997) Social skill and institutional theory. American Behavioral Scientist 40(4): $397-405$.

Fligstein, N (2001) Social skill and the theory of fields. Sociological Theory, 19(2): 105-125.

Fligstein N \& McAdam D (2011) Toward a general theory of strategic action fields. Sociological Theory, 29: 1-26.

Fligstein N (2013) Understanding stability and change in fields. Research in Organizational Behavior, 33: 39-51.

Garrick D (1757) Extract from David Garrick play. Capability Brown Exhibition. Kirkharle Courtyard. Northumberland.

Gephart RP (1993) The textual approach: Risk and blame in disaster sensemaking. Academy of Management Journal 36(6): 1465-1514.

Godfrey PC, Hassard J, O'Connor ES, Rowlinson M and Ruef M (2016) What is organizational history? Toward a creative synthesis of history and organization studies. Academy of Management Review 41(4): 590-608.

Goodman RS and Kruger EJ (1988) Data dredging or legitimate research method? Historiography and its potential for management research. Academy of Management Review 13(2): 315-325.

Goring P (2008) Eighteenth-century Literature and Culture. London: A\&C Black. 
Gottschalk L (1969) Understanding History: A Primer of Historical Method. New York: Alfred A. Knopf.

Greenwood R, Suddaby R and Hinings C (2002) Theorizing change: The role of professional associations in the transformation of institutionalized fields. Academy of Management Journal 45(1): 58-80.

Grenville R (1742) Agreement Book or 'bargain book'. (MS: GB 7 FR BUC11). The Museum of English Rural Life, Reading, UK.

Grey J (1769) Letter from Marchioness Grey to her Daughter-in-law. (MS: 30/9a/9/124). Lucas Papers, Bedfordshire Archive, Bedford.

Harrigan KR (1983) Research methodologies for contingency approaches to business strategy. Academy of Management Review 8(3): 398-405.

Hassard JS (2012) Rethinking the Hawthorne Studies: The Western Electric research in its social, political and historical context. Human Relations 65(11): 1431-1461.

Harvey C, Press J and Maclean M (2011) William Morris, cultural leadership and the dynamics of taste. Business History Review 85(2): 245-271.

Haveman HA and Rao H (1997) Structuring a theory of moral sentiments: institutional and organizational coevolution in the early thrift industry. American Journal of Sociology 102(6): 1606-1651.

Hawkes W (2005) The Diaries of Sanderson Miller of Radway. Warwick: The Dugdale Society.

Heracleous L and Barrett M (2001) Organizational change as discourse: Communicative actions and deep structures in the context of information technology implementation. Academy of Management Journal 44(4): 755-778.

Hodgson J and Hodgson-Hinde J (1827) A History of Northumberland: The Topography and Local Antiquities, Arranged in Parishes. Northumberland: E. Walker. 
Hoskin K and Macve R (1988) The genesis of accountability: The West Point connection. Accounting, Organization and Society 13(1): 37-73.

Howell MC and Prevenier W (2001) From Reliable Sources: An Introduction to Historical Methods. US: Cornell University Press.

Hyams E (1971) Capability Brown and Humphry Repton. London: Dent.

Jacques D (1978) Lancelot Brown: The professional man. Landscape Design 121: 24-27.

Johnson G and Hogg R (1864) Editorial Comments. Journal of Horticulture 7: 236-237.

Jones C and Jones D (1986) Peers, Politics and Power: House of Lords, 1603-1911. London: Bloomsbury Publishing.

Jones G and Khanna T (2006) Bringing history (back) into international business. Journal of International Business Studies 37(4): 453-468.

Kain R, Chapman J and Oliver R (2004) The Enclosure Maps of England and Wales. Cambridge, MA: Cambridge University Press.

Keppel G (1852) The memoirs of the Marquis of Rockingham and his contemporaries.

Kieser A (1994) Why organizational theory needs historical analyses and how this should be performed. Organization Science 5(4): 608-620.

Kipping M, Wadhwani D and Bucheli M (2014) Analyzing and interpreting historical sources: A basic methodology. In: Bucheli M and Wadhwani RD (eds), Organizations in Time: History, Theory, Methods. Oxford: Oxford University Press, 305 -329.

Langford P (1989) A Polite and Commercial people: England, 1727-83. US: Oxford University Press.

Langley A (1999) Strategies for theorizing from process data. Academy of Management Review 24(4): 691-710.

Lee AS (1991) Integrating positivist and interpretive approaches to organizational research. Organization Science 2(4): 342-365. 
Lisburne WV (1772) Letter from Lord Lisburne to Capability Brown. (MS 69795/35). Western Manuscripts Collection, British Library, London.

Lockett, A., Currie, G., Waring, J., Finn, R., Martin, G. (2014) The influence of social position on sensemaking about organizational change. Academy of Management Journal, 57: $1102-1129$.

Lounsbury M and Crumley ET (2007) New practice creation: An institutional perspective on innovation. Organization Studies 28(7): 993-1012.

Lowther (1763) Plans for the Park by Lancelot Brown. (MS DLONSL/11/3/1-6). Penrith: Cumbria Record Office.

Lucy G (1761) Letter from George Lucy of Charlecote Park. (MS: L06/1461). Warwickshire Record Office.

Lueger M, Sandner K, Meyer R and Hammerschmid G (2005) Contextualizing influence activities: An objective hermeneutical approach. Organization Studies 26(8): 1145-1168.

Maguire S and Hardy C (2009) Discourse and deinstitutionalization: The decline of DDT. Academy of Management Journal 52(1): 148-178.

Maguire S, Hardy C and Lawrence T (2004) Institutional entrepreneurship in emerging fields: HIV/AIDS treatment advocacy in Canada. Academy of Management Journal 47(5): 657-679.

Malins EG (1966) English Landscaping and Literature: 1660-1840. Oxford: Oxford University Press.

Martin JL (2003) What is field theory? American Journal of Sociology 109(1): 1- 49.

Meisenhelder T (1997) Pierre Bourdieu and the call for a reflexive sociology. Current Perspectives in Social Theory 17: 159-186.

Miller S (1749-1750) Diaries of Sanderson Miller. (MS: CR1382/1). Warwickshire County Record Office. Warwick, UK. 
Mouzelis N (1995) Sociological Theory: What Went Wrong?, London: Routledge.

Munir KA and Phillips N (2005) The birth of the 'Kodak moment': Institutional entrepreneurship and the adoption of new technologies. Organization Studies 26(11): $1665-1687$.

Musgrave T (2014) The Head Gardeners. London: Aurum Press.

Nahapiet J and Ghoshal S (1998) Social capital, intellectual capital, and the organizational advantage. Academy of Management Review 23: 242-266.

Newnham Paddox Building Record. (1743-1772). Record of the rebuilding of Newnham Paddox. (CR2017/A5). Warwickshire County Record Office. Warwick, UK.

Newton T (2010). Knowledge and practice: Organization studies within a historical and figurational context. Organization Studies 31(9-10): 1369-1395.

Olin L (2012). Across the Open Field: Essays Drawn from English Landscapes. US: University of Pennsylvania Press.

Olsen K (2017) Daily Life in 18th-century England. ABC-CLIO: California.

Palmer RE (1969) Hermeneutics: Interpretation theory in Schleiermacher, Dilthey, Heidegger, and Gadamer. Evanston: Northwestern University Press.

Passmore JA (1958) The objectivity of history. Philosophy 33(125): 97-111.

Phillips N and Brown JL (1993) Analyzing communication in and around organizations: A critical hermeneutic approach. Academy of Management Journal 36(6): 1547-1576.

Phillips N and Tracey P (2007) Opportunity recognition, entrepreneurial capabilities and bricolage: connecting institutional theory and entrepreneurship in strategic organization. Strategic Organization 5(3: 313.

Pitt W (1840) Correspondence of William Pitt, Earl of Chatham, Vol. 4. London: John Murray. 
Powell WW and Colyvas JA (2008) Microfoundations of institutional theory. In: Greenwood R, Oliver C, Sahlin K and Suddaby R (eds) The SAGE Handbook of Organizational Institutionalism. London: SAGE, 276-298

Rao H, Monin P and Durand R (2003) Institutional change in Toque Ville: Nouvelle cuisine as an identity movement in French gastronomy. American Journal of Sociology 108(4): 795-843.

Repton H and Loudon JC (1840) The Landscape Gardening and Landscape Architecture of the Late Humphrey Repton Esq. London: Longman.

Richardson T (2011) The Arcadian Friends. London: Random House.

Roberts W and More H (1835) Memoirs of the life and correspondence of Mrs. Hannah More. Vol. 2.

Sarasvathy SD (2001) Causation and effectuation: Toward a theoretical shift from economic inevitability to entrepreneurial contingency. Academy of Management Review 26(2): 243-263.

Sauder M (2008) Interlopers and field change: The entry of U.S. news into the field of legal education. Administrative Science Quarterly 53(2): 209 -234.

Shelburne (1757) Letter from the Earl of Shelburne to his son, Nov 2. Bowood House Archives, Wiltshire.

Seo M and Creed W (2002) Institutional contradictions, praxis, and institutional change: A dialectical perspective. Academy of Management Review 27(2): 222-247.

Smets M and Jarzabkowski P (2013) Reconstructing institutional complexity in practice: A relational model of institutional work and complexity. Human Relations 66(10): 12791309.

Smets M, Morris TIM and Greenwood R (2012) From practice to field: A multilevel model of practice-driven institutional change. Academy of Management Journal 55(4): 877-904. 
Smith C (1788) Emmeline: The Orphan of the Castle, Vol. 1. London: Broadview Press.

Stone L, Jeanne C and Stone F (1986). An Open Elite?: England, 1540-1880. Oxford: Oxford University Press.

Strong R (1998) The Story of Britain: A People's History. London: Pimlico.

Stroud D (1984) Capability Brown. London: Faber \& Faber.

Stowe Servants Wages. Stowe Volumes, Vol. 167. Huntington Library. San Marino, CA.

Suddaby R, Foster W and Mills A (2014) Historical institutionalism. In: Bucheli M and Wadhwani D (eds) Organizations in Time: History, theory, methods. Oxford: Oxford University Press, 100-123.

Suddaby R and Greenwood R (2005) Rhetorical strategies of legitimacy, Administrative Science Quarterly 50(1): 35-67.

Suddaby R and Viale T (2011) Professionals and field-level change: Institutional work and the professional project. Current Sociology 59(4): 423-442.

Tolbert P and Zucker L (1983) Institutional sources of change in the formal structure of organizations: The diffusion of civil service reform, 1880-1935. Administrative Science Quarterly 28(1): 22-39.

Trentham (1959) Plan for Trentham. (MS D593/H/13/1). Staffordshire Record Office. Tyne \& Wear County Council Museums (1883) Capability Brown and the Northern Landscape. Newcastle upon Tyne: TWAM.

Ventresca M and Mohr J (2002) Archival research methods. In: Baum JAC (ed) The Blackwell Companion to Organizations. Oxford: Blackwell, 805-828.

Verney MM and Abercrombie P (1926) Letters of an Eighteenth Century Architect, Sir Thomas Robinson Bart to Ralph 2nd Earl of Verney. Architectural Review 59: 258-263. 
Wadhwani RD and Jones G (2014) Schumpeter's plea: Historical reasoning in entrepreneurship theory and research. In: Bucheli M and Wadhwani RD (eds) Organizations in time: History, Theory, Method. Oxford: OUP, 192-216.

Walpole H (1840) The Letters of Horace Walpole, Earl of Orford: Including Numerous Letters now first published from the original manuscripts, Vol. 2. London: Bentley.

Walpole H (1848) Letters Addressed to the Countess of Ossory by Horace Walpole. London: Bentley.

Walpole H (1857) The Letters of Horace Walpole, Earl of Orford. Vol. 3. London: Bentley. Williamson T (1995) Polite Landscapes: Gardens and society in eighteenth-century England. London: Alan Sutton.

Wright AL and Zammuto RF (2013) Wielding the willow: Processes of institutional change in English county cricket. Academy of Management Journal 56(1): 308-330.

Zald MN (1993) Organization studies as a scientific and humanistic enterprise: Towards a reconceptualization of the foundations of the field. Organization Science 4(4): 513-528.

\section{Corresponding Author:}

Andrew Wild

University of Nottingham

Business School, Jubilee Campus, Wollaton Road, Nottingham, NG81BB. UK

T: 01158466605

andrew.wild@nottingham.ac.uk

\section{Other Author(s):}

Andy Lockett

Warwick Business School, University of Warwick, Warwick CV4 7AL, UK andy.lockett@wbs.ac.uk 
Graeme Currie

http://orcid.org/0000-0002-4825-9711

Warwick Business School, University of Warwick, Warwick CV4 7AL, UK graeme.currie@wbs.ac.uk 


\section{Manuscript version: Author's Accepted Manuscript}

The version presented in WRAP is the author's accepted manuscript and may differ from the published version or Version of Record.

\section{Persistent WRAP URL:}

http://wrap.warwick.ac.uk/111383

\section{How to cite:}

Please refer to published version for the most recent bibliographic citation information. If a published version is known of, the repository item page linked to above, will contain details on accessing it.

\section{Copyright and reuse:}

The Warwick Research Archive Portal (WRAP) makes this work by researchers of the University of Warwick available open access under the following conditions.

Copyright (C) and all moral rights to the version of the paper presented here belong to the individual author(s) and/or other copyright owners. To the extent reasonable and practicable the material made available in WRAP has been checked for eligibility before being made available.

Copies of full items can be used for personal research or study, educational, or not-for-profit purposes without prior permission or charge. Provided that the authors, title and full bibliographic details are credited, a hyperlink and/or URL is given for the original metadata page and the content is not changed in any way.

\section{Publisher's statement:}

Please refer to the repository item page, publisher's statement section, for further information.

For more information, please contact the WRAP Team at: wrap@warwick.ac.uk. 